\title{
Invasive weeds with pesticidal properties as potential new crops
}

\author{
Angela Mkindi ${ }^{1}$, Nelson Mpumi ${ }^{1}$, Yolice Tembo ${ }^{2}$, Phillip C. Stevenson ${ }^{3,4}$, Patrick A. Ndakidemi ${ }^{1}$, Kelvin \\ Mtei $^{1}$, Revocatus Machunda ${ }^{1}$, Steven R. Belmain ${ }^{4 *}$ \\ ${ }^{1}$ Nelson Mandela African Institution of Science and Technology, Arusha, Tanzania \\ ${ }^{2}$ Lilongwe University of Agriculture and Natural Resources, Malawi \\ ${ }^{3}$ Jodrell Laboratory, Royal Botanic Gardens, Kew, Richmond, Surrey, United Kingdom \\ ${ }^{4}$ Natural Resources Institute, University of Greenwich, Chatham Maritime, Kent, United Kingdom \\ *Corresponding author: Email: s.r.belmain@gre.ac.uk
}

\begin{abstract}
Plants with pesticidal properties have been investigated for decades as alternatives to synthetics, but only a handful have been commercialised and developed as non-food cash crops. One of the reasons why pesticidal plants are failing to deliver new pesticidal products is that they are often not evaluated under field conditions by farmers. Furthermore, many aspects of pesticide use related to environmental safety, such as their impact on beneficial organisms, remain under-evaluated. With a view to overcoming these bottlenecks, extracts made from six abundant weed species found across sub-Saharan Africa (Bidens pilosa, Lantana camara, Lippia javanica, Tithonia diversifolia, Tephrosia vogelii and Vernonia amygdalina) were evaluated in on-station and on-farm trials over two years (2015 and 2016) in two different countries (Tanzania and Malawi) on common bean plants (Phaseolus vulgaris). All plant species offered effective control of key pest species that was comparable in terms of harvested bean yield to a synthetic pyrethroid. Furthermore, the plant pesticide treatments had significantly lower negative effects on natural enemies (hover flies, lacewings, ladybird beetles and spiders). Thus, pesticidal plants were better able to support ecosystem services whilst effectively managing pests. Small holder farmer rankings on the perceived efficacy of the different plant species indicated that $T$. vogelii was the most preferred and effective, achieving bean yields as good as the synthetic, if not better. As T. vogelii is fast growing with a well-known and understood phytochemistry, it is an excellent candidate for commercial development to supplement pyrethrum production by African small holder farmers.
\end{abstract}

\section{Key words}

Pest control, non-food crops, pesticidal plants, botanical products, ecosystem services, legumes

\section{Introduction}

Common beans (Phaseolus vulgaris L.) (Fabales: Fabaceae) are rich in protein so are a critical food source for small holder African farmers but are also a good source of key nutrients for physical and 
mental development (Fuente Martínez et al., 2012; Messina, 1999). Insect pests are one of the most common constraints affecting production of beans and particularly affect production in sub-Saharan Africa (Food and Agriculture Organisation Statistics Division, 2015). Due to the severity of different insect pests affecting beans, many African farmers increasingly resort to frequent use of commercial synthetic pesticides (Abate and Ampofo, 1996). Such pest management practices are increasingly criticised as unsustainable and difficult to incorporate into agro-ecological intensification programmes aimed at developing sustainable agricultural practices and promoting ecosystem services (Bommarco et al., 2013; Pretty et al., 2011; Tittonell and Giller, 2013).

Plants with pesticidal properties have been investigated for decades as alternatives to synthetics, but little progress has been made to develop new products (Isman, 2008, 2006). Although research on pesticidal plants is increasing, it is failing to address gaps in our knowledge that constrain their adoption (Isman and Grieneisen, 2013). One of these gaps is their evaluation under realistic field conditions to assess their efficacy as well as whether their use can be beneficial to farmers. In comparison to concentrated synthetic products, pesticidal plants should be more environmentally benign due to their short persistence, naturally low concentrations of a more diverse suite of active ingredients and anti-feedant/repellent modes of action. Although there are some studies highlighting the relative benefits of pesticidal plants for ecosystem services, such as increased biological control (Amoabeng et al., 2013), there are relatively few studies which provide comparative evidence of ecosystem impact of synthetics and pesticidal plants under field conditions (Grzywacz et al., 2014).

Commercial production of non-food cash crops, such as pesticidal plants, can be a way to provide small holder farmers with alternative income sources (Sibhatu et al., 2015; Sola et al., 2014). The best example of this in Africa is the pyrethrum industry where many small holder farmers across several East African countries grow the chrysanthemum flower Tanacetum cinerariaefolium (Asterales: Compositae), selling the product to an international export market (Cassida, 2012). Efforts to increase pyrethrum production and to develop neem-based (Azadirachta indica) (Sapindales: Meliaceae) products in Africa have faced growing international competition from Australia, China, India and Brazil (Isman, 2004; Wilson, 2014). However, many other plant species with pesticidal properties have been documented to be used in sub-Saharan Africa (Anjarwalla et al., 2016; Belmain and Stevenson, 2001), many of which could have potential to be developed as new non-food crops. Particularly fast-growing weed species that are often highly abundant and invasive could be relatively easy to propagate at large scale for processing in to new botanical pesticides. Thus the aims of our study were to: 1) investigate the field use of pesticidal plants, particularly weed species that are widely available and 
abundant in bean production ecosystems, for insect pest control on common bean; 2) compare the effects of a common synthetic pesticide and pesticidal plants on the level of pest control and their potential effects on beneficial insect species; and 3) determine which plant species may be most suitable for development in to a natural pesticide as a non-food cash crop.

\section{Materials and methods}

\subsection{Study site}

The study was conducted at field sites in Tanzania and Malawi over two years. During 2015, a central field trial was carried out at Lyamungo, Hai District, Tanzania (Latitude $3^{\circ} 13^{\prime} 59.59^{\prime \prime}$ S Longitude $\left.37^{\circ} 14^{\prime} 54^{\prime \prime} \mathrm{E}\right)$. This was supported by 40 additional smaller field plots $(<$ ha) provided by 40 different small holder farmers around Hai District carrying out field trials over two cropping seasons (MarchJune 2015 and 2016). All field sites in Tanzania were at an elevation between 1100 to 1300 masl with a mean annual rainfall of $1200 \mathrm{~mm}$, mean maximum temperature of $21.7^{\circ} \mathrm{C}$ and mean minimum temperature of $13.6^{\circ} \mathrm{C}$. For Malawi, a central field trial was carried out during 2015 at Bunda, Mitundu, Malawi (Latitude $14^{\circ} 13^{\prime} .200 \mathrm{~S}$ Longitude $33^{\circ} 48.218 \mathrm{E}$ ). This was supported by 40 additional smaller field plots $(<$ ha) provided by 40 different small holder farmers around Mitundu carrying out field trials over two cropping seasons (January to April 2015 and 2016). All field sites in Malawi were at an elevation between 1100 and 1200 masl with a mean annual rainfall of $700 \mathrm{~mm}$, mean maximum temperature of $29^{\circ} \mathrm{C}$ and mean minimum temperature of $17^{\circ} \mathrm{C}$.

\subsection{Experimental design}

The central field trials were disc harrowed and ridged prior to planting. The common bean ( $P$. vulgaris) seeds used for planting were of the variety Lyamungo 90 in Tanzania and Kalima in Malawi. The seeds were planted at a spacing of $50 \mathrm{~cm}$ between rows and $20 \mathrm{~cm}$ within rows in $5 \times 5 \mathrm{~m}$ plots which were $1 \mathrm{~m}$ apart. Three seeds were seeded per hill and then thinned to two plants. Diammonium phosphate fertilizer was applied according to manufacturer's instructions during planting of the seeds. The experimental layout was a randomized complete block design, and the treatments were replicated on four blocks.

The 40 farmer fields in both countries had considerable variation in terms of land preparation and in the spacing of plants and we made no attempt to control these variables as we wanted to understand whether the pesticidal plant treatments would perform similarly under farmer field conditions. Furthermore, in order to reflect common bean growing practices in Tanzania, half of the farmers (20) 
planted beans as a mono-crop whilst the other half (20) planted beans as an intercrop with maize (Zea mays).

\subsection{Plant species collection and processing}

Fresh leaves of Tephrosia vogelii (Hook f.) (Fabales: Fabaceae), Vernonia amygdalina (Delile) (Asterales: Asteraceae), Lippia javanica (Burm.f.) Spreng. (Lamiales: Verbenaceae), Tithonia diversifolia (Hemsl.) A. Gray (Asterales: Asteraceae), Bidens pilosa L. (Asterales: Asteraceae) and Lantana camara L. (Lamiales: Verbenaceae) were collected from different locations around Hai District and Mitundu District (voucher specimens and GPS coordinates lodged at Nelson Mandela African Institution of Science and Technology, Arusha, Tanzania and Lilongwe University of Agriculture and Natural Resources, Bunda, Malawi). The first four plant species were included in all field and farm trials over 2015 and 2016. B. pilosa and L. camara were added to the farmer trials carried out in 2016. These six species were chosen due to their wide abundance around farms, roadsides and bushland, their familiarity to farmers and considerable existing knowledge on their efficacy, bioactive constituents and safety (Adedire and Akinneye, 2004; Adeniyi et al., 2010; Ambrósio et al., 2008; Asawalam et al., 2008; Bagnarello et al., 2009; Belmain et al., 2012; Gadzirayi et al., 2009; Ganjian et al., 1983; Gu et al., 2002; Kawuki et al., 2005; Madzimure et al., 2011; Mujovo et al., 2008; Oyewole et al., 2008; Pereira et al., 1997; Stevenson et al., 2012; Viljoen et al., 2005). To ensure uniformity, the leaves from each seasonal collection were mixed together for each species before drying. Leaves were dried under shade for a week and then crushed using a mill and sieved into a fine powder. Powders were stored in black plastic bags in dark, dry conditions until required.

\subsection{Field treatments}

For the 2015 field trial carried out in Tanzania and Malawi, three different concentrations of each of the four plant species (T. vogelii, V. amygdalina, L. javanica, $T$. diversifolia) were made $(0.1 \%, 1.0 \%$ and $10 \% \mathrm{w} / \mathrm{v}$ ) in order to determine potential concentration effects. In making all extracts, the correct amount of plant powder was weighed and added to water to extract at ambient temperature $\left(20 \pm 5^{\circ} \mathrm{C}\right)$ for 24 hours. In all cases $0.1 \%$ soap was added to the water during extraction as this has been shown previously to increase the extraction efficiency of nonpolar compounds present in the plant materials (Belmain et al., 2012). Extracts were kept in $10 \mathrm{I}$ buckets with lids in the shade and filtered through a fine cloth to remove all plant material that may inadvertently clog the sprayer. Negative controls consisted of water $+0.1 \%$ soap and water only. The positive control in all trials was synthetic pesticide Karate 5 EC (lambda-cyhalothrin pyrethroid, Syngenta) which was applied as per the manufacturers' instructions $(20 \mathrm{~g} / \mathrm{ha})$. All treatments and controls were replicated across four blocks. All treatments 
were sprayed throughout the growing season at an interval of 7 days starting one week after bean plant emergence. A 15-litre knapsack sprayer was used to apply the various treatments, and the sprayer was thoroughly cleaned with soap and water prior to being re-filled with another formulation for application.

For the $\mathbf{2 0 1 5}$ farmer trials, each farmer had eight treatments which were applied to different delimited areas of the crop field. To simplify the on-station protocol, farmers applied each of the four plant materials only at the highest rate of $10 \% \mathrm{w} / \mathrm{v}+0.1 \%$ soap. Each farmer also had three negative control plots (untreated, water only, water + soap) and a positive control (Karate). Each plot size was approximately $5 \mathrm{~m}^{2}$, with at least 2 metres distant between plots and all plots were at least 2 metres away from the crop field edge. Plot corners were staked, with string drawn around perimeter and labelled with the treatment name so that farmers would not confuse treatments. A further parameter at the farm level (in Tanzania only) was to involve farmers that planted beans as an intercrop with maize where rows of beans and maize alternated with each other, as well as farmers planting beans as a mono-cropped field. Individual plant spacing on farmer fields was not controlled but was similar to plant spacing used for the central field trials. As with the central on-station field trial, all farmer field treatments were sprayed at an interval of 7 days with a knapsack sprayer which was thoroughly cleaned with soap and water prior to being re-filled with another treatment.

For the 2016 farmer trials, at the request of farmers, two additional plant species (B. pilosa and $L$. camara) were added to the trial. To reduce the number of plot treatments, each farmer was provided with three of the six possible plant species, with each farmer receiving a unique combination of three different species. Thus, within each country each plant treatment was replicated 10 times, with each farmer having five different treatments (three plants species, negative (untreated) and positive (Karate) controls), for mono-cropped beans (Malawi and Tanzania) and intercropped beans with maize (Tanzania only). The same plots sizes and application regime was followed as in the previous year. As no single farmer had all six plant species treatments in their field, farmers were asked to rank the treatments they had from 1 to 5 in order to permit an amalgamated analysis of farmer preferences across all six plant species.

\subsection{Sampling for insect pest infestation and damage}

All assessments were carried out the day before treatments were to be sprayed. The target insect pests to be evaluated were aphids (Aphis fabae Scopoli) (Hemiptera: Aphididae), bean foliage beetle (Ootheca mutabilis (Schönherr) and O. bennigseni Weise) (Chrysomelidae: Galerucinae), flower beetle 
(Epicauta albovittata Gestro and E. limbatipennis Pic) (Coleoptera: Meloidae) and pod suckers (Clavigralla tomentosicollis Stål, C. schadabi Dolling, and C. hystricodes Stål) (Hemiptera: Coreidae). Three inner rows from each plot were selected for sampling. Ten plants in the selected three middle rows were counted and visually examined to record the number of plants infested by each insect pest, thus providing the percentage of plants infested (incidence), reporting the total insects on 10 plants/plot. The black bean aphid, A. fabae, was observed on bean plants for 10 weeks. Due to often very high numbers, a categorical index was used to assess aphid abundance, where $0=$ None; $1=A$ few scattered individuals; 2 = A few isolated colonies; 3 = Several isolated colonies; 4 = Large isolated colonies; and 5 = Large continuous colonies. For analytical purposes, this index was used as a proxy to report aphid numbers. Aphid damage was defined as wilted or blackened leaves (due to honeydew accumulation). The abundance of foliage beetle and flower beetle was determined by counting the total number. Field observations of bean foliage beetle and flower beetle were conducted during the 1st to 4th week and 5th to 8th week, respectively, after bean emergence. Two species of foliage beetle are known to be present in eastern and southern Africa, O. mutabilis and O. bennigseni (Grobbelaar, 2008). As they cause similar damage and are not easy to distinguish in the field, we did not attempt to identify their presence to the species level and recorded the total number of foliage beetle found during surveys. Ootheca damage is distinct, causing holes in the middle of leaves, and is distinct from other insect damage. The most common blister beetles in eastern and southern Africa are $E$. albovittata and E. limbatipennis (Hill, 2008); however, there are many similar-looking species causing similar damage, and we did not attempt to identify them at the species level. Locally, they are called flower beetles as the adults commonly eat the flowers of all pulse crops and other vegetables, again causing quite distinct damage at the flowering stage. Hemipteran pod-sucking bugs (Clavigralla spp.) are another common bean pest with several related species found in the region (Abate and Ampofo, 1996). Sucking damage to pods is quite distinctive and observed after pod development from the $5^{\text {th }}$ week onwards. The severity or degree of infestation in each infested plant was assessed by scoring the extent of damage using grades, where $0=$ No damage; 1 = Showing damage up to $25 \% ; 2=$ Damage from 26\%-50\%; 3 = Damage from 51\%-75\% and 4 = Damage more than 75\%. The abundance of four predatory species was also counted at each assessment period from their first appearance, including: ladybird beetles (adults and larvae) (Coccinellidae), spiders (Araneae), lacewings (Chrysopidae) and hoverflies (Syrphidae).

\subsection{Data Analysis}

Differences among treatments in insect incidence, abundance, damage and bean yield were assessed by analysis of variance (ANOVA) and Tukey's post-hoc Honestly Significant Difference (HSD) test to 
separate the means at the $95 \%$ confidence interval. Analyses were performed in XLSTAT version 2015.1.01 (Addinsoft, Paris, France).

\subsection{Ethics}

Ethical approval for the trials involving farmers was approved by the ethics committee of Nelson Mandela African Institution of Science and Technology for work in Tanzania and by the ethics committee of Lilongwe University of Agriculture and Natural Resources for work in Malawi. We also obtained verbal and written consent from each farmer assuring anonymity.

\section{Results}

\subsection{Pest abundance, crop damage and yield}

Results from the eight separate trials carried out over two years and two countries, with and without farmer involvement, all broadly show the same trends in terms of efficacy when measured over the cropping season through insect abundance and damage to bean plants as well as in the final yield of beans harvested. In all cases the commercial synthetic (Control +) was the most effective, the untreated control (Control -) always showed the greatest damage and insect numbers and the pesticidal plant treatments were typically more effective than the untreated plots but not as effective as the synthetic. However, the pesticidal plant treatments often performed as well as the synthetic in terms of bean yield despite them often having significantly higher numbers of insects and damage throughout the cropping season. An analysis of the on-station trials carried out in 2015 showed that insect numbers and damage were generally lower at the Tanzanian field site when compared to the Malawian field site (Fig. 1; ANOVA, $F=23.7, d f=6, P<0.01$ ). This difference may also help to partly explain the higher yields obtained in Tanzania, e.g. commercial synthetic yields of $800 \mathrm{~kg} / \mathrm{ha}$ and 650 $\mathrm{kg} / \mathrm{ha}$ in Tanzania and Malawi, respectively (ANOVA, $F=5.7, \mathrm{df}=6, \mathrm{P}<0.01$ ). In both trials, the yield obtained with the synthetic treatment was statistically comparable to the yields obtained with the average across all treatment concentrations for the four pesticidal plant species, whereas bean yields from the negative controls were significantly lower by approximately $200 \mathrm{~kg} / \mathrm{ha}$ (ANOVA, F = 5.7, df, = $6, P<0.01)$. Although the negative control which included $0.1 \%$ soap in the water did slightly reduce insect numbers and slightly increase yield compared to the water only control, the difference was not significant (ANOVA, $\mathrm{F}=1.2, \mathrm{df}=5, \mathrm{P}>0.01$ ). In both on-station trials, insect abundance and plant damage statistically separated into three groups: the negative controls, the plant treatments and the positive control (ANOVA, $F=23.7, d f=6, P<0.01$ ). Effects of concentration of the plant extract were apparent for all plant species following clear dose-response effects with insect abundance decreasing and bean yield increasing with increasing treatment concentration (Fig. 2; ANOVA, $F=14.4, d f=5, P$ 
$<0.01)$. The lowest concentration evaluated $(0.1 \% \mathrm{w} / \mathrm{v})$ was generally no better than the untreated control in terms of bean yield, whereas the highest concentration $(10 \% \mathrm{w} / \mathrm{v})$ provided a yield that was generally higher than the synthetic control (ANOVA, $F=52.3, d f=5, P<0.01$ ).

Trials carried out on small holder farmer fields in 2015 showed similar trends to that observed in the on-station trials (Fig 3.) Bean yields were higher in Tanzania than in Malawi. However, insect abundance and plant damage levels did not differ significantly across the two countries (ANOVA, F = $0.7, \mathrm{df}=17, \mathrm{P}>0.01$ ). As expected, yield was lowest for the untreated controls, and there was no statistically significant difference observed from the addition of soap alone when compared to water only or no treatment at all (ANOVA, $F=0.5, d f=2, P>0.01$ ). The effects of the four plant species treatments were similar to each other and performed as well as the synthetic control in terms of insect abundance, plant damage and bean yield (ANOVA, $\mathrm{F}=15.7, \mathrm{df}=7, \mathrm{P}<0.01$ ). However, a post-hoc analysis (Tukey's HSD) showed that bean yields with L. camara and V. amygdalina treatments were not different from the negative controls for mono-cropped and inter-cropped on-farm trials in Tanzania.

Farmer trials in Tanzania during 2016 showed similar patterns of efficacy where the untreated control was observed to have the lowest yield and highest insect abundance and damage rates, the synthetic control had the highest yield and lowest insect abundance and damage, and the effects of the pesticidal plant treatments were somewhere between the two (Fig. 4; ANOVA, $F=105.9, d f=15, P$ $<0.01$ ). A post-hoc analysis (Tukey's HSD) showed that of the six plant species evaluated, T. vogelii had the highest yield in both mono-cropped and inter-cropped beans in Tanzania, which was different from the positive and negative controls. All other plant species were not statistically different from the negative control. The observed results in Malawi were equivocal (Fig. 4). Although there was a slight trend for the untreated control to have higher insect abundance and damage, none of the treatments were statistically different from each other in the Malawi 2016 trial in terms of insect abundance, damage or yield. (ANOVA, $F=0.5, d f=6, P>0.01$ ). The likely reason for our results here is that bean cropping in central Malawi during 2016 was adversely affected by high rainfall late in the season, causing severe leaf blight that generally reduced bean plant vigour and yield. During 2016, farmers were additionally asked to rank the treatments based on their own observations. As each farmer had a different combination of three plant species out of the six available as well as positive and negative controls, farmers were asked to rank their five treatments, with 1 being the best and 5 being the worst. Mean rankings by farmers were consistent with the other measured parameters of damage and yield (Fig 4). There was generally broad agreement among farmers who ranked the 
untreated as the worst, the synthetic as the best, and the plant species somewhere between the two. From the rankings, there appeared to be a clear preference for $T$. vogelii, followed by $T$. diversifolia. Rankings for B. pilosa, L. camara, L. javanica and V. amygdalina suggest they were all equally effective and that farmers were generally unable to distinguish between them (ANOVA, $F=122.5, \mathrm{df}=7, \mathrm{P}<$ $0.01)$.

\subsection{Impact on beneficial arthropods}

In addition to pest insect abundance, key predatory insect species were also monitored on a weekly basis (Table 1). Consistent results across field trials were generally obtained that showed very low abundance of predators on synthetic pesticide treated plots when compared to the untreated and pesticidal plant treatments (ANOVA, $F=13.6, d f=7, P<0.01$ ). In most cases abundance of predators was similar between the pesticidal plant treatments and the untreated control (Table 1). Some significant differences in abundance were observed between mono-cropped and inter-cropped beans, particularly where hover fly and lacewing abundance was relatively higher on the intercropped fields (ANOVA, $\mathrm{F}=3.5, \mathrm{df}=15, \mathrm{P}<0.01$ ). However, this trend was not consistent for all predatory species and pesticidal plant treatments (Table 1 ).

\section{Discussion}

Our study suggests that commonly available pesticidal plant species in sub-Saharan Africa, often those considered as weeds and highly invasive, can be effectively used as botanical insecticides to control crop pests of common beans. These pesticidal species have been evaluated to control pests on a number of other crops as well (Asawalam et al., 2008; Bagnarello et al., 2009; Chagas-Paula et al., 2012), suggesting the plants could have broad application potential if commercialised. All six pesticidal species evaluated have orthodox seeds which are easy to harvest and propagate and are found over wide geographic areas of the world (Anjarwalla et al., 2016). As these species clearly grow over a range of habitats and are fast growing, prospects to grow and harvest plant material for the development of botanical pesticide products should be relatively easy to develop. The extent of knowledge on the phytochemistry of the species does vary, with $T$. vogelii the best studied in terms of knowledge about the chemistry and temporal variations (Belmain et al., 2012; Stevenson et al., 2012); however, phytochemical information is available for all the other species (Adeniyi et al., 2010; Ambrósio et al., 2008; Asawalam et al., 2008; Bartolome et al., 2013; Deba et al., 2008; Ganjian et al., 1983; Green et al., this issue; Gu et al., 2002; Khan et al., 2016; Mkenda et al., 2015; Mujovo et al., 2008; Pereira et al., 1997; Stevenson et al., 2012; Tesch et al., 2011; Viljoen et al., 2005). Producing any of these species 
as a non-food cash crop would need further evaluation to ensure elite materials were propagated and to fully understand their phytochemistry (Singh, 2014).

The research also highlights some of the challenges in carrying out field trials where results often vary across seasons and locations. Farmer participatory trials generally had higher yields than trials carried out on-station. For trials in 2015, farmers in Malawi and Tanzania attained higher yields than those achieved from on-station trials in the same year. Also, the yield difference between untreated and treated plots was less for farmer trials than observed in station trials. There are several possible reasons that could account for yield differences between station and farmer trials, such as differences in soil fertility or agronomic practices such as frequency of weeding or plant spacing. We did try to control for agronomic practices; however, results indicate such variables can make it difficult to compare across trials carried out in different locations and seasons, and particularly when involving farmers. The involved farmers were all experienced bean growers and thus perhaps simply better at achieving high yields compared to research staff operating the station trials.

Of the six plant species evaluated, $T$. vogelii was the most highly ranked by farmers in terms of efficacy. It was also the best species in terms of reducing insect numbers and damage and achieving a high yield of beans at harvest. The active constituents of $T$. vogelii are rotenoids, with deguelin and tephrosin being the most abundant bioactive constituents, with a relatively low presence of rotenone (Belmain et al., 2012; Stevenson et al., 2012). As rotenone has an established history of use in pest management long before the development of synthetic pesticides, the use of $T$. vogelii for pest management should be relatively straight forward in terms of registration and commercialisation (Ott, 2006). Although Derris spp. derived rotenone products have fallen out of favour in developed countries, they are still registered for use in organic crop production in the European Union, Canada, Australia and other countries. Environmental and safety issues of rotenoids are generally well-understood (Ling, 2002) and should not prevent the development of non-food cash crop products that contain naturally occurring levels of rotenoids (Belmain et al., 2012). T. vogelii is fast-growing with rotenoids present in leaf material, making it easy to harvest and process. It also has other uses that make it particularly suited to commercialisation, principally in soil improvement due to its relatively deep roots that mine minerals and fix nitrogen (Mafongoya et al., 2007; Snapp et al., 2002).

Previous research on the economics of using these pesticidal plant materials to protect small holder crops from pest damage, has shown such weedy species to be highly cost-beneficial when compared to commercial pesticides (Amoabeng et al., 2014; Mkenda et al., 2015). This is because many resource 
poor small holder farmers in sub-Saharan Africa find the cost of commercial products to be prohibitive, whereas the labour costs of collecting, processing and applying a plant extract from local abundant resources is generally cheaper. Particularly small holder farmers with limited income to buy pesticides will usually prefer to invest their labour as opposed to using cash inputs such as pesticides (Isman, 2008; Orr, 2003; Williamson et al., 2008). These different input costs are what make using pesticidal plants more profitable than synthetics. So, in our trials, although the commercial synthetic generally performed better at controlling insects on common beans, the level of insect control did not differ greatly from the plant-based pesticides. In the on-station trials the plant pesticides were generally more effective than the untreated control, and in some instances, were just as effective as the synthetic in terms of yield. However, in the farmer trials some of the plant species treatments did not perform as well, notably B. pilosa, L. camara, V. amygdalina, and L. javanica showed lower efficacy, whereas $T$. vogelii and $T$. diversifolia were more consistent across all the trials. Developing local production of pesticidal plants as a commercial crop with a view to local selling to other farmers could be a way to provide farmers with relatively cheaper pest control options. Financially incentivised propagation and processing of local plants would help overcome the main challenges of small holder farm use of pesticidal plants by increasing plant species abundance and reducing the manual labour involved in processing plant materials. Such production models already exist for the collection of plants for medicinal and cosmetic purposes as well as the established natural pesticides pyrethrum ( $T$. cinerariaefolium) and neem (Azadirachta indica) (Sokoni, 2008; Sola et al., 2014). Plant-based pesticide products could be sold locally and more cheaply compared to imported synthetics. This would provide small holder farmers with more sustainable pest control options and help overcome several of the problems currently encountered with synthetics (availability, cost, adulteration, resistance, human health, environmental and non-target effects, and general mis-use) (Dinham, 2003; Ngowi et al., 2007).

With respect to non-target risks, our current study showed that impacts on beneficial insects were much lower with the pesticidal plant treatments than that observed with the commercial synthetic. This is likely due the short persistence of the plant extracts, where many of the active ingredients are known to be UV-labile and prone to wash off and break down in the soil (Miresmailli and Isman, 2014). Lower risk also occurs due to the relatively low level active constituents naturally found in plant leaves of which only a portion are extracted in to water (plus $0.1 \% \mathrm{v} / \mathrm{v}$ soap). Indeed, low activity and low persistence of crudely extracted plant materials may be considered unfavourable by farmers wishing to kill insects quickly without the need to frequently re-apply. The trade-off is that higher numbers of beneficial arthropods are maintained when using pesticidal plant treatments, and these beneficial 
species can contribute to pest control and prevent the pest resurgence that commonly occurs after using synthetic pesticides (Gurr et al., 2016; Li and Yang, 2015). The need for more frequent application of a non-persistent natural pesticide could also have other benefits. Discussion with the farmers in our trials suggest that the plant extracts may be acting as a crop fertilizer as well as helping to control bacterial and fungal pathogens. Although we did not evaluate these parameters in our trials, other research suggests these effects could explain the higher yields we observed when using pesticidal plant extracts (Eugenia et al., 2015; Isman, 2000; Pretali et al., 2016). We plan to evaluate these parameters in future field trials.

Throughout sub-Saharan Africa, small holder farmers often inter-crop beans with maize, to benefit from the nitrogen fixing properties of legumes that helps improve their maize yield (Mucheru-Muna et al., 2010; Ngwira et al., 2012). Our research shows that there may also be some benefit to the bean plants by improving the micro-climate and habitat for some predatory species such as hover flies and lacewings. These two species were more abundant in inter-cropped fields and may benefit from the shade provided by the maize plants or even food resources such as maize pollen (Verkerk et al., 1998). Inter-cropping has long been argued to reduce pest incidence (Trenbath, 1993); however, our research does not generally indicate that pest insect abundance was lower for beans that were inter-cropped with maize compared to mono-cropped beans. As many other pest and predatory species are found on bean crops, the data from our research are certainly not able to determine if there was any significant difference in total pest pressure between inter-cropped and mono-cropped beans. Further studies are required to understand the value of pest management strategies which can also protect and facilitate ecosystem services.

Our study used widely available, weedy plant species, which are relatively easy to collect and process and could be developed in to new cash crops for small holder farm use in sub-Saharan Africa and elsewhere. Many other plant species with known pesticidal properties are not always abundant in local areas, e.g. neem and pyrethrum, due to their endemic habitat limitations, and may principally contain highly non-polar active ingredients that are generally more difficult to extract (Gallo et al., 2017; Garg et al., 1994). Higher costs of using rare or difficult-to-process plant species could change the economics of their use in favour of synthetics or more readily available plant species, even when such products may be relatively more effective. In conclusion, our field trials suggest using commonly available weeds with pesticidal properties can make both economic sense for farmers whilst also being less harmful to the environment and consumers. The potential to produce and exploit weeds as non- 
food cash crops merits further investigation in order to optimise ecosystem services and improve financial rates of return to farmers who choose to use pesticidal plants.

\section{Acknowledgements}

We thank the technical field assistance provided by staff at the Tanzania Coffee Research Institute (TaCRI), Damas Mnyang'ali for assistance at NMAIST and Maxwell Katulu, Haighten Francis, Aubrey Kaphukusi, Luci Ng'ambani and Late Sempulo Kanthiti at LUANR as well as the involved farmers for providing the experimental field sites and their participation in the trial. This research was funded by

a McKnight Foundation grant (Grant No: 13-335) https://www.mcknight.org/grantprograms/international/collaborative-crop-research and a European Union 9th European Development Fund grant from the African Caribbean and Pacific Science and Technology Programme (FED/2013/329-272) http://www.acp-st.eu/. The funders had no role in study design, data collection and analysis, decision to publish, or preparation of the manuscript.

\section{References}

Abate, T., Ampofo, J.K., 1996. Insect pests of beans in Africa: their ecology and management. Annu. Rev. Entomol. 41, 45-73. doi:10.1146/annurev.en.41.010196.000401

Adedire, C.O., Akinneye, J.O., 2004. Biological activity of tree marigold, Tithonia diversifolia, on cowpea seed bruchid, Callosobruchus maculatus (Coleoptera: Bruchidae). Ann. Appl. Biol. 144, 185-189. doi:10.1111/j.1744-7348.2004.tb00332.x

Adeniyi, S.A., Orjiekwe, C.L., Ehiagbonare, J.E., Arimah, B.D., 2010. Preliminary phytochemical analysis and insecticidal activity of ethanolic extracts of four tropical plants (Vernonia amygdalina, Sida acuta, Ocimum gratissimum and Telfaria occidentalis) against beans weevil (Acanthscelides obtectus). Int. J. Phys. Sci.

Ambrósio, S.R., Oki, Y., Heleno, V.C.G., Chaves, J.S., Nascimento, P.G.B.D., Lichston, J.E., Constantino, M.G., Varanda, E.M., Da Costa, F.B., 2008. Constituents of glandular trichomes of Tithonia diversifolia: relationships to herbivory and antifeedant activity. Phytochemistry 69, 2052-60. doi:10.1016/j.phytochem.2008.03.019

Amoabeng, B.W., Gurr, G.M., Gitau, C.W., Nicol, H.I., Munyakazi, L., Stevenson, P.C., 2013. Tritrophic insecticidal effects of African plants against cabbage pests. PLoS One 8, e78651. doi:10.1371/journal.pone.0078651

Amoabeng, B.W., Gurr, G.M., Gitau, C.W., Stevenson, P.C., 2014. Cost:benefit analysis of botanical insecticide use in cabbage: Implications for smallholder farmers in developing countries. Crop Prot. 57, 71-76. doi:10.1016/j.cropro.2013.11.019

Anjarwalla, P., Belmain, S.R., Sola, P., Jamnadass, R., Stevenson, P.C., Stevenson, 2016. Handbook on pesticidal plants, ICRAF. World Agroforestry Centre, Nairobi, Kenya.

Asawalam, E.F., Emosairue, S.O., Hassanali, A., 2008. Contribution of different constituents to the toxicity of the essential oil constituents of Vernonia amygdalina (Compositae) and Xylopia aetiopica (Annonaceae) on maize weevil, Sitophilus zeamais Motschulsky (Coleoptera: Curculionidae). African J. Biotechnol. doi:10.5897/AJB08.121

Bagnarello, G., Hilje, L., Bagnarello, V., Cartín, V., Calvo, M., 2009. Phagodeterrent activity of the plants Tithonia diversifolia and Montanoa hibiscifolia (Asteraceae) on adults of the pest insect Bemisia tabaci (Homoptera: Aleyrodidae). Rev. Biol. Trop. 57, 1201-15.

Bartolome, A.P., Villaseñor, I.M., Yang, W.-C., Yang, W.-C., 2013. Bidens pilosa L. (Asteraceae): 
Botanical Properties, Traditional Uses, Phytochemistry, and Pharmacology. Evid. Based. Complement. Alternat. Med. 2013, 340215. doi:10.1155/2013/340215

Belmain, S.R., Amoah, B.A., Nyirenda, S.P., Kamanula, J.F., Stevenson, P.C., 2012. Highly Variable Insect Control Efficacy of Tephrosia vogelii Chemotypes. J. Agric. Food Chem. 60, 10055-10063. doi:10.1021/jf3032217

Belmain, S.R., Stevenson, P.C., 2001. Ethnobotanicals in Ghana: Revising and modernising age-old farmer practice. Pestic. Outlook 6, 233-238. doi:10.1039/B110542F

Bommarco, R., Kleijn, D., Potts, S.G., 2013. Ecological intensification: harnessing ecosystem services for food security. Trends Ecol. Evol. 28, 230-8. doi:10.1016/j.tree.2012.10.012

Cassida, J.E. (ed), 2012. Pyrethrum: The Natural Insecticide. Elsevier Science, New York, USA.

Chagas-Paula, D.A., Oliveira, R.B., Rocha, B.A., Da Costa, F.B., 2012. Ethnobotany, chemistry, and biological activities of the genus Tithonia (Asteraceae). Chem. Biodivers. 9, 210-35. doi:10.1002/cbdv.201100019

Deba, F., Xuan, T.D., Yasuda, M., Tawata, S., 2008. Chemical composition and antioxidant, antibacterial and antifungal activities of the essential oils from Bidens pilosa Linn. var. Radiata. Food Control 19, 346-352. doi:10.1016/j.foodcont.2007.04.011

Dinham, B., 2003. Growing vegetables in developing countries for local urban populations and export markets: problems confronting small-scale producers. Pest Manag. Sci. 59, 575-582. doi:10.1002/ps.654

Eugenia, T., Elena, E., Michaela, B., Maria, O., Florin, O., Cristian, I., 2015. Biological action of plant extracts on a fungal plant biostimulant strain of Trichoderma viride. Acta Horti Bot. Bucurest 42, 63-66. doi:10.1515/ahbb-2015-0007

Food and Agriculture Organisation Statistics Division, 2015. FAOSTAT [WWW Document]. URL http://faostat3.fao.org/home/E (accessed 3.3.17).

Fuente Martínez, M. de la, López-Pedrouso, M., Alonso, J., Santalla Ferradás, M., Ron Pedreira, A.M. de, Álvarez, G., Zapata, C., 2012. In-depth characterization of the phaseolin protein diversity of common bean (Phaseolus vulgaris L.) based on two-dimensional electrophoresis and mass spectrometry. Food Technol. Biotechnol. 50, 315-325.

Gadzirayi, C.T., Mutandwa, E., Mwale, M., Chindundu, T., 2009. Utilization of Tephrosia vogelii in controlling ticks in dairy cows by small-scale commercial farmers in Zimbabwe. African J. Biotechnol. 8, 4134-4136. doi:10.5897/AJB2009.000-9396

Gallo, M., Formato, A., Ianniello, D., Andolfi, A., Conte, E., Ciaravolo, M., Varchetta, V., Naviglio, D., 2017. Supercritical fluid extraction of pyrethrins from pyrethrum flowers (Chrysanthemum cinerariifolium) compared to traditional maceration and cyclic pressurization extraction. J. Supercrit. Fluids 119, 104-112. doi:10.1016/j.supflu.2016.09.012

Ganjian, I., Kubo, I., Fludzinski, P., 1983. Insect antifeedant elemanolide lactones from Vernonia amygdalina. Phytochemistry 22, 2525-2526. doi:10.1016/0031-9422(83)80154-X

Garg, S., Talwar, G.P., Upadhyay, S.N., 1994. Comparison of extraction procedures on the immunocontraceptive activity of neem seed extracts. J. Ethnopharmacol. 44, 87-92. doi:10.1016/0378-8741(94)90073-6

Grobbelaar, E., 2008. On the identity of Ootheca bennigseni Weise, O. mutabilis (Schönherr) and O. meridiana sp. n. (Chrysomelidae: Galerucinae), bean and cowpea pests in the Afrotropical Region. African Entomol. 16, 7-22. doi:10.4001/1021-3589-16.1.7

Grzywacz, D., Stevenson, P.C., Mushobozi, W.L., Belmain, S.R., Wilson, K., 2014. The use of indigenous ecological resources for pest control in Africa. Food Secur. 6, 71-86. doi:10.1007/s12571-013-0313-5

Gu, J.-Q., Gills, J.J., Park, E.J., Mata-Greenwood, E., Hawthorne, M.E., Axelrod, F., Chavez, P.I., Fong, H.H.S., Mehta, R.G., Pezzuto, J.M., Kinghorn, A.D., 2002. Sesquiterpenoids from Tithonia diversifolia with potential cancer chemopreventive activity. J. Nat. Prod. 65, 532-536. doi:10.1021/np010545m

Gurr, G.M., Lu, Z., Zheng, X., Xu, H., Zhu, P., Chen, G., Yao, X., Cheng, J., Zhu, Z., Catindig, J.L., 
Villareal, S., Van Chien, H., Cuong, L.Q., Channoo, C., Chengwattana, N., Lan, L.P., Hai, L.H., Chaiwong, J., Nicol, H.I., Perovic, D.J., Wratten, S.D., Heong, K.L., 2016. Multi-country evidence that crop diversification promotes ecological intensification of agriculture. Nat. Plants 2, 16014. doi:10.1038/nplants.2016.14

Hill, D.S., 2008. Pests of Crops in Warmer Climates and Their Control. Springer Science \& Business Media, Dordrecht, Netherlands.

Isman, M.B., 2008. Botanical insecticides: For richer, for poorer. Pest Manag. Sci. 64, 8-11. doi:10.1002/ps.1470

Isman, M.B., 2006. Botanical insecticides, deterrents, and repellents in modern agriculture and an increasingly regulated world. Annu. Rev. Entomol. 51, 45-66. doi:10.1146/annurev.ento.51.110104.151146

Isman, M.B., 2004. Factors Limiting Commercial Success of Neem Insecticides in North America and Western Europe, in: Neem: Today and in the New Millennium. Kluwer Academic Publishers, Dordrecht, pp. 33-41. doi:10.1007/1-4020-2596-3_3

Isman, M.B., 2000. Plant essential oils for pest and disease management. Crop Prot. 19, 603-608. doi:10.1016/S0261-2194(00)00079-X

Isman, M.B., Grieneisen, M.L., 2013. Botanical insecticide research: many publications, limited useful data. Trends Plant Sci. 19, 1-6. doi:10.1016/j.tplants.2013.11.005

Kawuki, R.S., Agona, A., Nampala, P., Adipala, E., 2005. A comparison of effectiveness of plant-based and synthetic insecticides in the field management of pod and storage pests of cowpea. Crop Prot. 24, 473-478. doi:10.1016/j.cropro.2004.09.017

Khan, M., Mahmood, A., Alkhathlan, H.Z., 2016. Characterization of leaves and flowers volatile constituents of Lantana camara growing in central region of Saudi Arabia. Arab. J. Chem. 9, 764-774. doi:10.1016/j.arabjc.2015.11.005

Li, Y.C., Yang, Y., 2015. On the paradox of pesticides. Commun. Nonlinear Sci. Numer. Simul. 29, 179187. doi:10.1016/j.cnsns.2015.05.006

Ling, N., 2002. Rotenone-a review of its toxicity and use for fisheries management. Sci. Conserv. 211, 1-40.

Madzimure, J., Nyahangare, E.T., Hamudikuwanda, H., Hove, T., Stevenson, P.C., Belmain, S.R., Mvumi, B.M., 2011. Acaricidal efficacy against cattle ticks and acute oral toxicity of Lippia javanica (Burm F.) Spreng. Trop. Anim. Health Prod. 43, 481-9. doi:10.1007/s11250-010-9720-1

Mafongoya, P.L., Bationo, A., Kihara, J., Waswa, B.S., 2007. Appropriate technologies to replenish soil fertility in southern Africa. Nutr. Cycl. Agroecosystems 76, 137-151. doi:10.1007/s10705-0069049-3

Messina, M.J., 1999. Legumes and soybeans: overview of their nutritional profiles and health effects. Am. J. Clin. Nutr. 70, 439S-450S.

Miresmailli, S., Isman, M.B., 2014. Botanical insecticides inspired by plant-herbivore chemical interactions. Trends Plant Sci. 19, 29-35. doi:10.1016/j.tplants.2013.10.002

Mkenda, P., Mwanauta, R., Stevenson, P.C., Ndakidemi, P., Mtei, K., Belmain, S.R., 2015. Extracts from field margin weeds provide economically viable and environmentally benign pest control compared to synthetic pesticides. PLoS One. doi:10.1371/journal.pone.0143530

Mucheru-Muna, M., Pypers, P., Mugendi, D., Kung'u, J., Mugwe, J., Merckx, R., Vanlauwe, B., 2010. A staggered maize-legume intercrop arrangement robustly increases crop yields and economic returns in the highlands of Central Kenya. F. Crop. Res. 115, 132-139. doi:10.1016/j.fcr.2009.10.013

Mujovo, S.F., Hussein, A.A., Meyer, J.J.M., Fourie, B., Muthivhi, T., Lall, N., 2008. Bioactive compounds from Lippia javanica and Hoslundia opposita. Nat. Prod. Res. 22, 1047-54. doi:10.1080/14786410802250037

Ngowi, A.V.F., Mbise, T.J., ljani, A.S.M., London, L., Ajayi, O.C., 2007. Pesticides use by smallholder farmers in vegetable production in Northern Tanzania. Crop Prot. 26, 1617-1624. doi:10.1016/j.cropro.2007.01.008 
Ngwira, A.R., Aune, J.B., Mkwinda, S., 2012. On-farm evaluation of yield and economic benefit of short term maize legume intercropping systems under conservation agriculture in Malawi. $F$. Crop. Res. 132, 149-157. doi:10.1016/j.fcr.2011.12.014

Orr, A., 2003. Integrated Pest Management for Resource-Poor African Farmers: Is the Emperor Naked? World Dev. 31, 831-845. doi:10.1016/S0305-750X(03)00015-9

Ott, K.C., 2006. Rotenone. A Brief Review of its Chemistry, Environmental Fate, and the Toxicity of Rotenone Formulations [WWW Document]. URL http://www.newmexicotu.org/Rotenone summary.pdf

Oyewole, I.O., Ibidapo, C.A., Moronkola, D.O., Oduola, A.O., Adeoye, G.O., Anyasor, G.N., Obansa, J.A., 2008. Anti-malarial and repellent activities of Tithonia diversifolia (Hemsl.) leaf extracts. J. Med. Plants Res. 2, 171-175.

Pereira, P.S., Dias, D.A., Vichnewski, W., Tucci Nasi, A.M.T., Herz, W., 1997. Sesquiterpene lactones from Brazilian Tithonia diversifolia. Phytochemistry 45, 1445-1448. doi:10.1016/S00319422(97)00142-8

Pretali, L., Bernardo, L., Butterfield, T.S., Trevisan, M., Lucini, L., 2016. Botanical and biological pesticides elicit a similar Induced Systemic Response in tomato (Solanum lycopersicum) secondary metabolism. Phytochemistry 130, 56-63. doi:10.1016/j. phytochem.2016.04.002

Pretty, J., Toulmin, C., Williams, S., 2011. Sustainable intensification in African agriculture. Int. J. Agric. Sustain. 9, 5-24. doi:10.3763/ijas.2010.0583

Sibhatu, K.T., Krishna, V. V, Qaim, M., 2015. Production diversity and dietary diversity in smallholder farm households. Proc. Natl. Acad. Sci. U. S. A. 112, 10657-62. doi:10.1073/pnas.1510982112

Singh, D., 2014. Advances in plant biopesticides. Springer, New Delhi. doi:10.1007/978-81-322-20060

Snapp, S.S., Rohrbach, D.D., Simtowe, F., Freeman, H.A., 2002. Sustainable soil management options for Malawi: can smallholder farmers grow more legumes? Agric. Ecosyst. Environ. 91, 159-174. doi:10.1016/S0167-8809(01)00238-9

Sokoni, C.H., 2008. Commercialisation of smallholder production in Tanzania: implications for sustainable resources management. Geogr. J. 174, 158-161. doi:10.1111/j.14754959.2008.00287.x

Sola, P., Mvumi, B.M., Ogendo, J.O., Mponda, O., Kamanula, J.F., Nyirenda, S.P., Belmain, S.R., Stevenson, P.C., 2014. Botanical pesticide production, trade and regulatory mechanisms in subSaharan Africa: making a case for plant-based pesticidal products. Food Secur. 6, 369-384. doi:10.1007/s12571-014-0343-7

Stevenson, P.C., Kite, G.C., Lewis, G.P., Forest, F., Nyirenda, S.P., Belmain, S.R., Sileshi, G.W., Veitch, N.C., 2012. Distinct chemotypes of Tephrosia vogelii and implications for their use in pest control and soil enrichment. Phytochemistry 78, 135-146. doi:10.1016/j.phytochem.2012.02.025

Tesch, N.R., Mora, F., Rojas, L., Díaz, T., Velasco, J., Yánez, C., Rios, N., Carmona, J., Pasquale, S., 2011. Chemical composition and antibacterial activity of the essential oil of Lantana camara var. moritziana. Nat. Prod. Commun. 6, 1031-4.

Tittonell, P., Giller, K.E., 2013. When yield gaps are poverty traps: The paradigm of ecological intensification in African smallholder agriculture. F. Crop. Res. 143, 76-90. doi:10.1016/j.fcr.2012.10.007

Trenbath, B.R., 1993. Intercropping for the management of pests and diseases. F. Crop. Res. 34, 381405. doi:10.1016/0378-4290(93)90123-5

Verkerk, R.H.J., Leather, S.R., Wright, D.J., 1998. The potential for manipulating crop-pest-natural enemy interactions for improved insect pest management. Bull. Entomol. Res. 88, 493. doi:10.1017/S0007485300026018

Viljoen, A.M., Subramoney, S., van Vuuren, S.F., Başer, K.H.C., Demirci, B., 2005. The composition, geographical variation and antimicrobial activity of Lippia javanica (Verbenaceae) leaf essential oils. J. Ethnopharmacol. 96, 271-7. doi:10.1016/j.jep.2004.09.017 
Williamson, S., Ball, A., Pretty, J., 2008. Trends in pesticide use and drivers for safer pest management in four African countries. Crop Prot. 27, 1327-1334. doi:10.1016/j.cropro.2008.04.006

Wilson, C.R., 2014. Robustness of Industrial Crops in High Production Cost Agricultural Systems Dealing with Market Flux. Med. Aromat. Plants 3. doi:10.4172/2167-0412.1000e150 
Table 1. Treatment effect on abundance of key beneficial arthropod species during on-station and on-farm bean cropping trials in 2015 and 2016 in the countries of Tanzania and Malawi.

\begin{tabular}{|c|c|c|c|c|c|c|c|c|c|}
\hline \multirow{4}{*}{ Treatment } & \multirow{4}{*}{ Species } & \multicolumn{5}{|c|}{ Tanzania } & \multicolumn{3}{|c|}{ Malawi } \\
\hline & & \multicolumn{3}{|c|}{2015 trials } & \multicolumn{2}{|c|}{2016 trials } & \multicolumn{2}{|c|}{2015 trials } & 2016 trials \\
\hline & & \multicolumn{2}{|c|}{ Mono-cropped } & \multirow{2}{*}{$\begin{array}{c}\text { Inter-cropped } \\
\text { On-farm } \\
\end{array}$} & \multirow{2}{*}{$\begin{array}{c}\text { Mono-cropped } \\
\text { On-farm }\end{array}$} & \multirow{2}{*}{$\begin{array}{c}\text { Inter-cropped } \\
\text { On-farm } \\
\end{array}$} & \multicolumn{3}{|c|}{ Mono-cropped } \\
\hline & & On-station & On-farm & & & & On-station & On-farm & On-farm \\
\hline \multirow{4}{*}{ Control - } & Hover fly & $1.2^{\mathrm{a}}$ & $1.5^{\mathrm{b}}$ & $0.9^{\mathrm{a}}$ & $0.0^{\mathrm{b}}$ & $0.3^{c}$ & $2.0^{\mathrm{b}}$ & $1.9^{\mathrm{a}}$ & $2.2^{\mathrm{a}}$ \\
\hline & Lacewing & $1.5^{\mathrm{a}}$ & $2.2^{\mathrm{a}}$ & $1.5^{\mathrm{a}}$ & $0.0^{\mathrm{b}}$ & $0.1^{\mathrm{c}}$ & $0.0^{c}$ & $0.0^{c}$ & $0.5^{\mathrm{a}}$ \\
\hline & Ladybird & $7.3^{\mathrm{a}}$ & $2.9^{a}$ & $2.2^{\mathrm{a}}$ & $1.1^{\mathrm{a}}$ & $1.1^{\mathrm{a}}$ & $3.0^{\mathrm{b}}$ & $1.2^{\mathrm{b}}$ & $4.1^{\mathrm{a}}$ \\
\hline & Spider & $9.1^{\mathrm{a}}$ & $1.4^{\mathrm{b}}$ & $1.3^{\mathrm{a}}$ & $0.7^{\mathrm{ab}}$ & $0.8^{\mathrm{ab}}$ & $2.6^{\mathrm{b}}$ & $0.1^{\mathrm{c}}$ & $2.0^{\mathrm{a}}$ \\
\hline \multirow{3}{*}{ Control + } & Hover fly & $0.1^{\mathrm{c}}$ & $0.1^{\mathrm{c}}$ & $0.1^{\mathrm{c}}$ & $0.0^{\mathrm{b}}$ & $0.5^{b}$ & $1.0^{\mathrm{b}}$ & $1.2^{\mathrm{b}}$ & $0.0^{\mathrm{b}}$ \\
\hline & Ladybird & $0.0^{c}$ & $0.2^{\mathrm{c}}$ & $0.2^{\mathrm{c}}$ & $0.0^{\mathrm{b}}$ & $0.1^{\mathrm{c}}$ & $1.0^{\mathrm{b}}$ & $0.6^{\mathrm{bc}}$ & $0.0^{\mathrm{b}}$ \\
\hline & Spider & $0.1^{c}$ & $0.2^{\mathrm{c}}$ & $0.1^{c}$ & $0.0^{\mathrm{b}}$ & $0.2^{\mathrm{c}}$ & $0.0^{c}$ & $0.1^{c}$ & $0.0^{\mathrm{b}}$ \\
\hline \multirow{4}{*}{ L. camara } & Hover fly & $1.7^{\mathrm{ab}}$ & $0.5^{c}$ & $0.7^{\mathrm{b}}$ & $0.1^{\mathrm{b}}$ & $0.7^{\mathrm{b}}$ & $1.3^{\mathrm{b}}$ & $2.0^{a}$ & $3.2^{\mathrm{a}}$ \\
\hline & Lacewing & $1.5^{\mathrm{ab}}$ & $1.7^{\mathrm{b}}$ & $1.9^{\mathrm{a}}$ & $0.0^{\mathrm{b}}$ & $0.8^{\mathrm{ab}}$ & $3.3^{b}$ & $0.0^{c}$ & $1.1^{\mathrm{a}}$ \\
\hline & Ladybird & $1.9^{\mathrm{b}}$ & $1.8^{\mathrm{b}}$ & $1.2^{\mathrm{a}}$ & $0.3^{\mathrm{b}}$ & $0.9^{\mathrm{ab}}$ & $0.7^{c}$ & $1.1^{\mathrm{b}}$ & $0.9^{a}$ \\
\hline & Spider & $5.1^{\mathrm{b}}$ & $1.1^{\mathrm{b}}$ & $0.9^{b}$ & $0.4^{b}$ & $0.8^{\mathrm{ab}}$ & $1.3^{\mathrm{b}}$ & $0.2^{c}$ & $0.1^{\mathrm{ab}}$ \\
\hline \multirow{3}{*}{ T. diversifolia } & Hover fly & $0.8^{\mathrm{c}}$ & $0.3^{c}$ & $0.4^{b}$ & $0.3^{b}$ & $0.5^{b}$ & $5.7^{\mathrm{a}}$ & $1.7^{\mathrm{a}}$ & $2.4^{\mathrm{a}}$ \\
\hline & Lacewing & $1.5^{\mathrm{ab}}$ & $2.0^{\mathrm{b}}$ & $0.9^{a}$ & $0.0^{\mathrm{b}}$ & $0.6^{\mathrm{b}}$ & $0.0^{c}$ & $0.0^{c}$ & $2.4^{\mathrm{a}}$ \\
\hline & Ladybird & $1.8^{\mathrm{b}}$ & $1.3^{\mathrm{b}}$ & $0.9^{a}$ & $0.8^{\mathrm{a}}$ & $0.6^{\mathrm{b}}$ & $8.7^{a}$ & $1.2^{\mathrm{b}}$ & $1.1^{\mathrm{a}}$ \\
\hline \multirow{4}{*}{ T. vogelii } & Hover fly & $0.7^{c}$ & $0.2^{c}$ & $0.3^{\mathrm{bc}}$ & $0.9^{a}$ & $1.0^{\mathrm{a}}$ & $6.3^{\mathrm{a}}$ & $1.9^{a}$ & $2.1^{\mathrm{a}}$ \\
\hline & Lacewing & $1.5^{\mathrm{ab}}$ & $1.5^{\mathrm{b}}$ & $1.7^{\mathrm{a}}$ & $1.2^{\mathrm{a}}$ & $0.2^{c}$ & $0.0^{c}$ & $0.0^{c}$ & $1.0^{\mathrm{a}}$ \\
\hline & Ladybird & $2.9^{\mathrm{b}}$ & $1.9^{\mathrm{b}}$ & $0.9^{\mathrm{a}}$ & $0.2^{\mathrm{b}}$ & $0.5^{\mathrm{b}}$ & $4.0^{\mathrm{b}}$ & $1.1^{\mathrm{b}}$ & $0.9^{a}$ \\
\hline & Spider & $4.5^{\mathrm{b}}$ & $1.2^{\mathrm{b}}$ & $0.5^{\mathrm{b}}$ & $0.3^{b}$ & $0.4^{\mathrm{bc}}$ & $2.7^{b}$ & $0.2^{c}$ & $0.4^{\mathrm{a}}$ \\
\hline \multirow{4}{*}{ V. amygdalina } & Hover fly & $0.9^{c}$ & $0.4^{\mathrm{bc}}$ & $0.7^{b}$ & $1.4^{\mathrm{a}}$ & $0.3^{\mathrm{bc}}$ & $11.3^{\mathrm{a}}$ & $2.3^{\mathrm{a}}$ & $3.0^{\mathrm{a}}$ \\
\hline & Lacewing & $1.3^{\mathrm{b}}$ & $1.9^{\mathrm{b}}$ & $1.1^{\mathrm{a}}$ & $1.5^{\mathrm{a}}$ & $0.1^{\mathrm{c}}$ & $0.0^{c}$ & $0.0^{c}$ & $0.5^{\mathrm{a}}$ \\
\hline & Ladybird & $3.5^{\mathrm{b}}$ & $1.3^{\mathrm{b}}$ & $0.9^{\mathrm{b}}$ & $0.7^{\mathrm{ab}}$ & $0.3^{\mathrm{bc}}$ & $4.0^{\mathrm{b}}$ & $1.6^{\mathrm{a}}$ & $1.3^{\mathrm{a}}$ \\
\hline & Spider & $4.5^{b}$ & $1.2^{\mathrm{b}}$ & $0.7^{\mathrm{b}}$ & $0.5^{\mathrm{b}}$ & $0.2^{\mathrm{c}}$ & $2.3^{\mathrm{b}}$ & $0.1^{\mathrm{c}}$ & $0.1^{\mathrm{b}}$ \\
\hline \multirow{4}{*}{ B. pilosa } & Hover fly & $*$ & $*$ & $*$ & $0.2^{\mathrm{b}}$ & $0.5^{b}$ & $*$ & $*$ & $3.5^{\mathrm{a}}$ \\
\hline & Lacewing & $*$ & $*$ & $*$ & $0.0^{\mathrm{b}}$ & $0.4^{\mathrm{bc}}$ & $*$ & $*$ & $1.2^{\mathrm{a}}$ \\
\hline & Ladybird & $*$ & $*$ & $*$ & $0.7^{\mathrm{ab}}$ & $0.6^{\mathrm{b}}$ & $*$ & $*$ & $1.1^{\mathrm{a}}$ \\
\hline & Spider & $*$ & $*$ & $*$ & $0.3^{b}$ & $0.7^{\mathrm{b}}$ & $*$ & $*$ & $0.3^{\mathrm{ab}}$ \\
\hline \multirow{4}{*}{ L. javanica } & Hover fly & $*$ & $*$ & $*$ & $0.3^{\mathrm{b}}$ & $0.5^{b}$ & $*$ & $*$ & $3.5^{a}$ \\
\hline & Lacewing & $*$ & $*$ & $*$ & $0.0^{\mathrm{b}}$ & $0.2^{c}$ & $*$ & $*$ & $1.2^{\mathrm{a}}$ \\
\hline & Ladybird & $*$ & $*$ & $*$ & $0.7^{\mathrm{ab}}$ & $0.6^{\mathrm{b}}$ & $*$ & $*$ & $1.4^{\mathrm{a}}$ \\
\hline & Spider & $*$ & $*$ & $*$ & $0.4 b$ & $0.4^{b c}$ & $*$ & $*$ & $0.4^{\mathrm{a}}$ \\
\hline
\end{tabular}

Abundance values are the average number of arthropods recorded over the sampling period. Values in the same column followed by the same letter are not significantly different from each other at the $95 \%$ confidence interval using Tukey's post-hoc Honestly Significant Difference (HSD) test. * not evaluated during this season. 
Figure 1. Key pest abundance, crop damage and yield observed on bean plants in on-station field trials during the 2015 cropping season A) in Tanzania and B) in Malawi. Plant treatments are the average across the three concentrations. Aphid abundance is measured with a 0-5 index and is therefore a proxy for actual aphid numbers.

Figure 2. Effect of pesticidal plant extract concentration on bean crop yield and key arthropod abundance A) in Tanzania on-station trial and B) in Malawi on-station trial. Aphid abundance is measured with a 0-5 index and is therefore a proxy for actual aphid numbers.

Figure 3. Key pest abundance, crop damage and yield observed in farmer field trials during 2015 cropping season in A) Tanzania inter-cropped beans, B) Tanzania mono-cropped beans and C) Malawi mono-cropped beans. Aphid abundance is measured with a 0-5 index and is therefore a proxy for actual aphid numbers.

Figure 4. Key pest abundance, crop damage, farmer ranking and yield observed in farmer field trials during 2016 cropping season in A) Tanzania inter-cropped beans, B) Tanzania mono-cropped beans and C) Malawi mono-cropped beans. Aphid abundance is measured with a 0-5 index and is therefore a proxy for actual aphid numbers. 